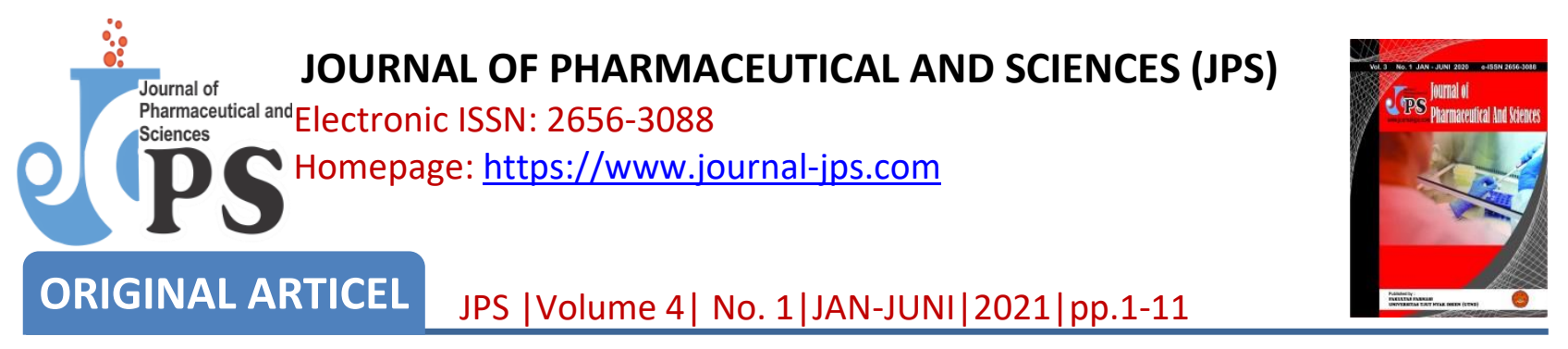

\title{
ANTIMICROBIAL ACTIVITY JANGJINGKI (Oxalis corniculata L.) AGAINST THE GROWTH OF Staphylococcus Aureus, Escherichia Coli, AND Candida Albicans
}

\section{AKTIVITAS ANTIMIKROBA JANGJINGKI (Oxalis corniculata L.) TERHADAP PERTUMBUHAN BAKTERI Staphylococcus Aureus, Escherichia Coli DAN JAMUR Candida Albicans}

\author{
Misrahanum ${ }^{1}$, Syarifah Dhea Almunawwarah ${ }^{1,}$ Hira Helwati ${ }^{2}$,Hilda Maysarah ${ }^{1}$, Sadli ${ }^{1}$ \\ 'Jurusan Farmasi, FMIPA, Universitas Syiah Kuala - Banda Aceh, Indonesia. \\ 2Jurusan Kimia, FMIPA, Universitas Syiah Kuala - Banda Aceh, Indonesia. \\ Email : misra.hanum@unsyiah.ac.id
}

\begin{abstract}
Jangjingki (Oxalis corniculata L.) is a plant from Oxalidaceae that has potential as a natural antimicrobial agent. The purpose of this research is to see the antimicrobial activity of methanol extract of jangjingki against the growth of Staphylococcus aureus ATCC 25923, Escherichia coli ATCC 25922, and Candida albicans ATCC 10231. The thick extract of jangjingki was obtained by the maceration method with methanol solvent. At the same time, the antimicrobial activity test on $\mathrm{S}$. aureus and $\mathrm{E}$. Coli bacteria was carried out using the hole diffusion method. The simplicia characterization showed $7.17 \%$ water, $9.68 \%$ of total ash, $11.67 \%$ water-soluble extract, and $9.17 \%$ of the ethanol-soluble section. At the same time, the methanol extract of jangjingki characterization showed $22.5 \%$ of water, $10.16 \%$ of total ash, $55.83 \%$ water-soluble extract, and $62.91 \%$ of the ethanol-soluble section. Phytochemical test results showed that the methanol extract of jangjingki contains alkaloids, saponins, flavonoids, tannins, and steroids. The results of the antimicrobial activity test with variations in the concentration of jangjingki methanol extract $15,20,30$, and $40 \%$ on $S$. aureus and $E$. Coli bacteria showed growth inhibition activity of these two bacteria, the largest diameter of the inhibition zone was formed when the extract was given a concentration of $40 \%$ with a diameter of the area. Resistance of $8,07 \mathrm{~mm}$ and $11 \mathrm{~mm}$, respectively. Meanwhile, the test results of inhibition of growth of the fungus $C$. Albicans by presenting variations in the concentration of jangjingki methanol extract of $5,10,15$, and $20 \%$ could not inhibit the growth fungus $C$. Albicans.
\end{abstract}

Keywords : Antimicrobial, jangjingki, methanol extract, Staphylococcus aureus, Escherichia coli, Candida albicans.

\section{ABSTRAK}

Jangjingki (Oxalis corniculata L.) salah satu tumbuhan dari famili Oxalidaceae yang berpotensi sebagai antimikroba alami. Tujuan dari penelitian adalah untuk melihat aktivitas antimikroba ekstrak metanol jangjingki terhadap pertumbuhan bakteri Staphylococcus aureus ATCC 25923, Escherichia coli ATCC 25922, dan jamur Candida albicans ATCC 10231. Ekstrak diperoleh melalui metode maserasi dan uji aktivi- 
tas antimikroba dengan metode difusi sumuran. Hasil karakterisasi simplisia menunjukkan kadar air sebesar $7,17 \%$, kadar abu total 9,68\%, kadar sari larut air 11,67\%, dan kadar sari larut etanol 9,17\% Sementara karakterisasi ekstrak menunjukkan kadar air sebesar 22,5\%, kadar abu total 10,16\%, kadar sari larut air $55,83 \%$, dan kadar sari larut etanol 62,91\%. Uji fitokimia ekstrak jangjingki mengandung senyawa alkaloid, saponin, flavonoid, tanin, dan steroid. Hasil uji aktivitas antimikroba dengan variasi konsentrasi ekstrak metanol jangjingki 15, 20, 30 dan 40\% pada bakteri S. Aureus dan E. Coli menunjukkan aktifitas penghambatan pertumbuhan kedua bakteri tersebut, diameter zona hambat terbesar terbentuk pada pemberian ekstrak dengan konsentrasi $40 \%$ dengan diameter zona hambat berturut-turut sebesar $8,07 \mathrm{~mm}$ dan $11 \mathrm{~mm}$. Sedangkan hasil uji aktifitas penghambatan pertumbuhan jamur $C$. Albicans dengan pemberian variasi konsentrasi ekstrak metanol jangjingki sebesar $5,10,15$, dan $20 \%$ tidak dapat menghambat pertumbuhan jamur $C$. albicans.

Kata kunci : Antimikroba, jangjingki, ekstrak metanol, Staphylococcus aureus, Escherichia coli, Candida albicans.

\section{INTRODUCTION}

Indonesia is one of the countries with many natural resources in all regions, with most of the plants being medically nutritious. People of Indonesia have long been using natural resources as traditional medicine for curing many diseases, including infection (Dzulkarnain et al., 2004). Many microorganisms cause infection, for example, protozoa, viruses, parasites, worms, algae, fungus, and bacteria.

Microbes that are natural flora of the human body do not cause disease but in some conditions, such as skin infections by $\mathrm{S}$. aureus bacteria, gastrointestinal infections by $E$. coli bacteria, and C. Albicans (Brooks) fungal infections. et al., 2007). Infections caused by microbes can be cured using synthetic medicine, which is antibiotics, but the irrational usage can cause antibiotics resistance. Because of that, research nowadays on potentially natural ingredients as medicine has done a lot to reduce the case of antibiotics resistance as one of the alternative treatments to find new antimicrobial that is very sensitive and effective(Candrasari et al., 2012 \& Herwin dan Nuryanti, 2012).

Jangjingki plant (Oxalis corniculata L.) (Picture 1) is one of the plants from the family of Oxalidaceae that has been used as traditional medicine by society (Herwin dan Nuryanti, 2012). Empirically in India, jangjingki is used to cure dysentery, diarrhea, indigestion, skin disease, and an anti-inflammatory (Raghavendra et al., 2006 dan Handali et al., 2011). Other than that, fresh jangjingki leaves can be used to stop bleeding by crushing it (Siddiqui et al., 2017). Jangjingki was also reported to have anthelmintic activity (Dighe et al., 2012), antioxidant (Ahmed et al., 2013), as well as antifungal and antibacterial activity (Mohan and Pandey, 2016). In Indonesia, Jamu jangjingki has been used to cure sore throat, flu, fever, and diarrhea (Herwin and Nuryanti, 2012). Whereas in Aceh, precisely in the Bener Meriah district, people have traditionally consumed plants only as worm medicine by drinking a liquid mixed with garlic (Gayo, 2018).

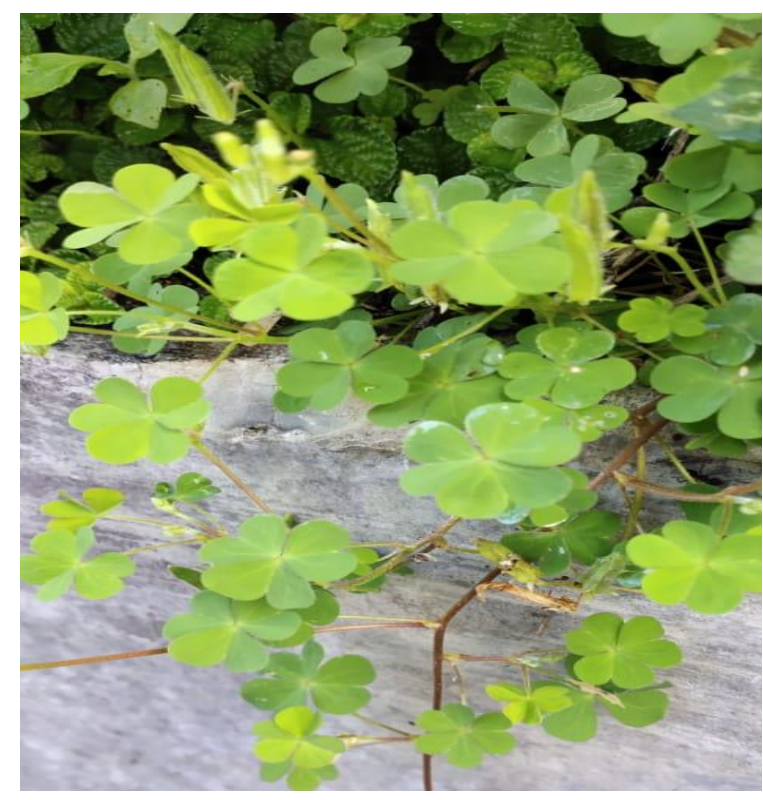

Picture 1. Jangjingki (Oxalis Corniculata) 
Raghavendra et al. (2006) said that jangjingki leaf contained phenolics, tannins compound, carbohydrates and glycosides, phytosterols, flavonoids, proteins, amino acids. Research to Siddiqui et al. (2017), jangjingki leaf contained alkaloids, tannins, phenolics compound, flavonoids, carbohydrates, proteins, and sterols. Dighe et al. (2012) reported that jangjingki herbs showed phenolics compounds, carbohydrates, alkaloids, proteins, flavonoids, steroids, saponins, tannins, and glycosides. Other than that, it can be used as an anthelmintic because it contains tannins, alkaloids, flavonoids, and saponins (Gayo, 2018).

Handali et al. (2011) reported that $20 \%$ concentration of jangjingki leaf water extract has an inhibition zone against S. aureus ATCC 29737 is $21 \mathrm{~mm}$, and against $E$. coli ATCC 8739 is 19,33 $\mathrm{mm}$. Mohan and Pandey (2016) reported that petroleum ether extract of jangjingki leaf could inhibit S. aureus in $100 \%$ concentration with the diameter of inhibition zone respectively is 17,25 $\mathrm{mm}$. Based on Tibuhwa (2016), water extract of jangjingki leaf have inhibition zone diameter against E. coli ATCC 25922 is $7,5 \mathrm{~mm}$ and against C. Albicans ATCC 90028 is $4 \mathrm{~mm}$. Herwin dan Nuryanti (2012) said that the squeeze herbs of $O$. corniculata in $50 \%$ concentration from inhibition zone diameter against $\mathrm{S}$. aureus are $12,00 \mathrm{~mm}$, and $\mathrm{E}$. coli is 20,33 against $C$. Albicans is 15,00 $\mathrm{mm}$.

Based on said above, knowing that jangjingki has antibacterial activity against $S$. aureus, E. coli, dan C. Albicans, from the research that has been done, generally using leaf extract, but no one has done herb extract activity from jangjingki. In this research, the jangjingki herb that is used is from Aceh Tengah, Indonesia.

\section{RESEARCH METHOD}

\section{Sampling Method}

Sampling technique done using the purposive sampling method, sample characteristic taken is fresh jangjingki, green color with $5-35 \mathrm{~cm}$ length. Taken part is a whole plant except the stems.

\section{Tools}

Tools used here are Laminar Air Flow
Cabinet (LAFC), Spektrofotometer UV-VIS, autoclave, Rotary Evaporator, vortex, hot plate, incubator, Erlenmeyer, Vernier calipers.

\section{Ingredients}

The ingredients used are jangjingki, $S$. aureus bacteria, E. coli bacteria, C. Albicans fungus, Mueller Hinton Agar (MHA) media, Sabouraud Dextrose Agar (SDA) media, amoxicillin, gentamicin, nystatin, Methanol.

\section{Simplicia Preparation}

The first step in simplicia is wet sorting of 7.5 kilograms of jangjingki plants, which aims to separate them from impurities and other plants. The next stage is washing the jangjingki plant, which aims to clean the dirt in the sample. Washed jangjingki plants, dried in air at room temperature, protected from direct sunlight. The simplicia was mashed and re-weighed to determine the weight of the simplicia obtained (Menkes RI, 2009).

\section{Preparation of jangjingki Methanol Extract}

Simplicia powder macerated with a ratio of simplicia and solvent is $1: 10$. Then, the vessel is covered with aluminum foil and saved in place out of direct sunlight for five days while stirring occasionally. After five days, the macerate is filtered with filter paper. The macerate obtained is kept, then filtration waste is macerated with methanol solvent left for two days, then filters. Macerate obtained is concentrated in a rotary evaporator at $50^{\circ} \mathrm{C}$ to obtain thick extract (Anief, 2010).

\section{Characterization of simplicia and extract}

Characterization of simplicia and the extract included the determination of water content, water-soluble juice content, ethanolsoluble juice content, and total ash content.

\section{Phytochemistry Screening}

Phytochemical screening contains alkaloids, flavonoids, tannins, saponins, steroids, and terpenoids.

\section{Preparation Inoculum Microbe Suspension}

$S$. aureus, E. coli, and C. Albicans were taken from culture stock using an Ose needle and suspended inside the test tube, which has $5 \mathrm{~mL}$ of $\mathrm{NaCl} 0,9 \%$-then homogenized with vortex. Next, 
test the absorbance by using sa spectrophotometer in $600 \mathrm{~nm}$ wavelength (Denovix Inc, 2017) for bacteria and $530 \mathrm{~nm}$ for fungus (WHO, 2009).

\section{Liquid Concentration of Jangjingki Methanol Extract}

Jangjingki Methanol Extract obtained is made into several concentrations like 15, 20, 30, dan $40 \%$ for bacteria dan $5,10,15$ dan $20 \%$ for fungus.

\section{Antimicrobial Activity}

Test of antimicrobial activity is done using healthy diffusion method, with pouring method. The suspense of $1 \mathrm{~mL} S$. aureus and $E$. coli are taken and into respective Erlenmeyer with $30 \mathrm{~mL}$ of MHA media sterilized. Then, shake the Erlenmeyer until homogeneous so that media and suspense mix perfectly. Suspension of $C$. Albicans that has been customized with McFarland 0,5 standard is swabbed evenly in the surface of SDA media that has condensed using a sterilized cotton bud. Next, make a well or hole that has $6 \mathrm{~mm}$ diameters. Each hole fills with $30 \mu \mathrm{L}$ jangjingki methanol extract with $15,20,30$, and $40 \%$ concentration for bacteria, $5,10,15$, and $20 \%$ concentration for fungus, amoxicillin $1 \%$, gentamicin $4 \%$ dan nystatin as a positive control, and Methanol as a negative control. Media with bacteria inside is incubated at $37^{\circ} \mathrm{C}$ for 24 hours (Yusriana et al., 2014 dan Nuryanti et al., 2016), while media with the fungus was incubated at $37^{\circ} \mathrm{C}$ for 2-3 days (Litaay et al., 2017). Three times repetition. The clear zone that is made is observed and measured the diameter by using vernier calipers.

\section{RESULTS AND DISCUSSIONS}

Jangjingki simplicia that has been dry sorted, has resulted in $975 \mathrm{~g}$ with a $13 \%$ yield. Jangjingki simplicia powder results at $880 \mathrm{~g}$. Simplicia in powder has the purpose of reducing the shape of simplicia. It also increases simplicia surface area so that the contact between the surface of simplicia with solvent will be higher. The solvent will penetrate inside the simplicia, so secondary metabolites compound extracted at maximum (Husni et al., 2018).

Maceration obtained from maceration and maceration is mixed and filtered through a rotary evaporator at $50^{\circ} \mathrm{C}$ until we have condensed extract. Evaporation aims to vaporize the solvent used until only the jangjingki active compounds are left (Reo et al., 2017). The thick methanol extract of jangjingki obtained is $62,38 \mathrm{~g}$ with $7,8 \%$ yield extract; according to Nur et al. (2019), a higher yield extract signifies a higher dynamic content inside resulted extract. Jangjingki methanol extract is a dark green color with a thick consistency and typical smell of jangjingki.

\section{Phytochemistry Screening}

Phytochemistry screening showed that jangjingki methanol extract contained alkaloids, flavonoids, tannins, saponins, and steroids (Table 1).

Tabel 1. Result of phytochemistry test of jangjingki methanol extract

\begin{tabular}{|c|l|c|c|c|}
\hline No. & \multicolumn{1}{|c|}{ Parameter Uji } & Pereaksi & Hasil Pengamatan & Ket. \\
\hline \multirow{2}{*}{1.} & \multirow{2}{*}{ Alkaloids } & Mayer & Clear yellow solution & - \\
\cline { 3 - 5 } & & Bouchard & Brown sediments & + \\
\cline { 3 - 5 } & & Deggendorf & Orange-yellow sediments & + \\
\hline 2. & Flavonoids & powder $\mathrm{Mg}+\mathrm{HCl}$ pure & Orange-yellow solution & + \\
\hline 3. & Tannins & $\mathrm{FeCl}_{3} 10 \%$ & Dark green solution & + \\
\hline 4. & Saponins & $\mathrm{H}_{2} \mathrm{O}+\mathrm{HCl}_{2} \mathrm{~N}$ & Foam formed $(2,7 \mathrm{~cm})$ & + \\
\hline 5. & Steroids/Triterpenoids & $\mathrm{CH}_{3} \mathrm{COOH}+\mathrm{H}_{2} \mathrm{SO}_{4}$ pekat & Dark green solution & + +- \\
\hline
\end{tabular}

Note:

$(+)$ : have secondary metabolites

$(-)$ : no secondary metabolites 
Antibacterial Activity Test

Results of antimicrobial activity are seen from clear zone formed around the well. Measurement of apparent zone diameter is done using vernier calipers. The presence of a clear zone that is formed signifies that jangjingki methanol extract can inhibit the development of microbes. Results of the antibacterial activity test can be seen in table 2 .

Table 2. Results of measurement of antibacterial activity test jangjingki methanol extract against S.aureus and E. coli

\begin{tabular}{|c|c|c|}
\hline \multirow{2}{*}{$\begin{array}{c}\text { Jangjingki methanol extract } \\
\text { concentration (\%) }\end{array}$} & \multicolumn{2}{|c|}{ Average of inhibition zone diameters (mm) \pm SD } \\
\cline { 2 - 3 } & S. aureus ATCC 25923 & E. coliATCC 25922 \\
\hline 15 & $6,97 \pm 0,49$ & $9,36 \pm 1,36$ \\
\hline 20 & $7,33 \pm 0,38$ & $10 \pm 1,4$ \\
\hline 30 & $7,83 \pm 0,46$ & $10,87 \pm 0,61$ \\
\hline 40 & $8,07 \pm 0,49$ & $11 \pm 1,31$ \\
\hline Control positive & $29,43 \pm 0,25$ & $21,13 \pm 0,76$ \\
\hline Control negative & $0 \pm 0$ & $0 \pm 0$ \\
\hline
\end{tabular}

Note:

Control positive: S. aureus: Amoxicillin 1\%

E. coli: Gentamicin 4\%

Control negative: Methanol solvent

Based on Table 2, jangjingki extract inhibits the development of $\mathrm{S}$. aureus dan $\mathrm{E}$. coli with different inhibition zones in each concentration. The result of the highest inhibition zone diameter against $S$. aureus and $E$. coli is at the highest concentration, $40 \%$, with an average diameter of inhibition zone, obtained respectively at $8,07 \mathrm{~mm}$ and $11 \mathrm{~mm}$ with weak and medium category. This shows that jangjingki methanol extract can inhibit $S$. aureus and $E$. Coli (Picture 2 and picture 3).

The diameter of the inhibition zone that is formed is higher along with the increase of used concentration. Extract concentration is higher shows that more secondary metabolites inside the extract. This shows that the higher the value of antibacterial substance released where high extract concentration can increase penetration of antibacterial compounds inside bacteria cells to spoil cells metabolism, which ended in lysis (death) for cells (Lingga et al., 2016). The ability of antibacterial substances in inhibiting the development of bacteria depends on the nature of bacteria itself, extract concentration, media, and test method, and extract diffusion speed in the media (Candrasari et al., 2012).

The difference between inhibition zone resulting from $\mathrm{S}$. Aureus and $\mathrm{E}$. Coli is in structure difference of cells wall that by both bacterias, which influences the work of methanol extract of jangjingki antibacterial compounds cells to wall structure gram-positive bacteria is more simple than gram-negative. Cells wall of gram-positive bacteria consists of a thick layer of peptidoglycan with small lipids that form out stiff cell structure and contains teichoic acid, which is soluble in water that signifies that this cell's wall of bacteria more polar. This creates a more accessible way to extract bacteria's cells wall (Tansil et al., 2016).

While gram-negative cell wall structure is more complex dan more layered, it causes several compounds to spoil this bacteria cell wall tissue. It is difficult for active compounds that potentially antibacterial to come inside. The cell wall arranges with more lipids component, thin peptidoglycans, and an outer membrane consisting of 
phospholipids, lipopolysaccharides which is a complex lipid. Antibacterial molecules with relatively larger sizes will cause slower penetration of the outer membrane, thus causing Gram bacteria to be more resistant to antibacterials (Pratiwi, 2008).

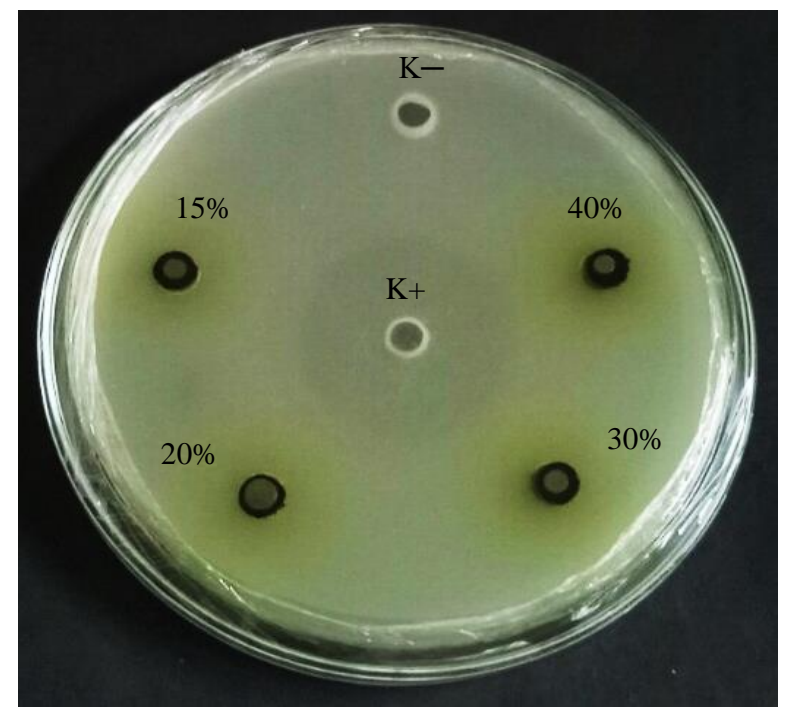

Picture 2. Test results of antibacterial activity of jangjingki methanol extract against bacteria S. Aureus.

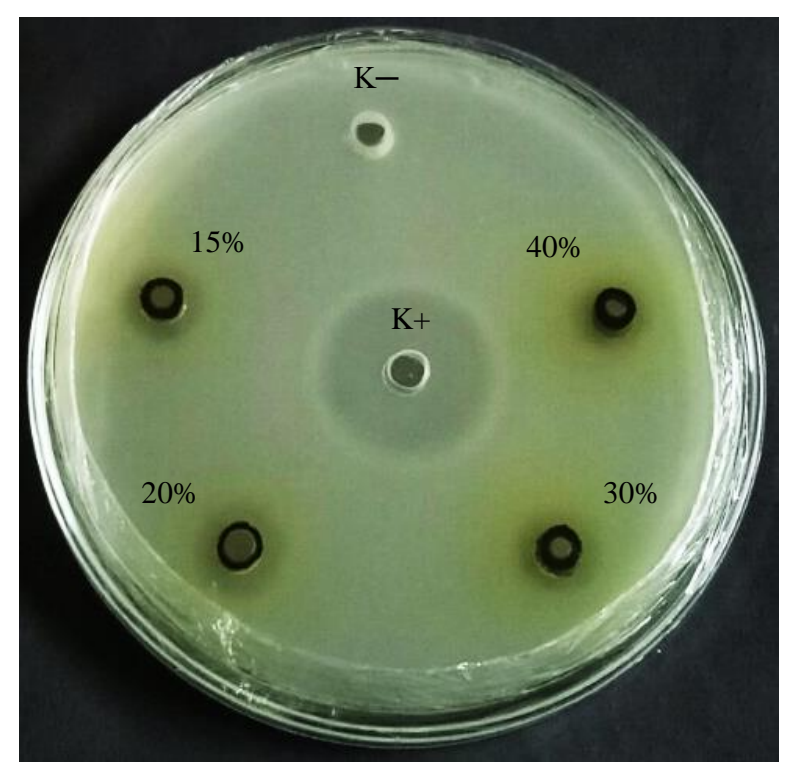

Picture 3. Test results of antibacterial activity of jangjingki methanol extract against bacteria E. Coli.

Based on differences in the cell wall structure, the cell wall of gram-positive bacteria is more accessible to destroy than the cell wall of gram-negative bacteria. However, the antibacterial activity methanol extract of jangjingki obtained from this research shows that the diameter of the inhibition zone that is formed is higher against $E$. coli than $S$. aureus. This is presumed that secondary metabolites compound inside jangjingki methanol extract actively inhibit gram-negative bacteria than gram-positive. The type content of secondary metabolites compound inside this plant can give different activation as different antibacterial even in the same group.

The inhibition zone of Jangjingki methanol extract against the growth of $\mathrm{S}$. aureus bacteria is a weak category. In contrast, the zone of inhibition for the growth of $E$. coli was categorized as moderate-weak, as shown in Table 4.6. showed that jangjingki methanol extract had activity in inhibiting the development of $\mathrm{S}$. aureus and $\mathrm{E}$. coli. However, the inhibition zone diameter resulting from jangjingki methanol extract is far lower than the amoxicillin inhibition zone and gentamicin, which is used as a positive control, where amoxicillin in $S$. aureus has an inhibition zone at $29,43 \mathrm{~mm}$. In contrast, gentamicin in $E$. coli has an inhibition zone at $21,13 \mathrm{~mm}$. The result signifies that amoxicillin and gentamicin still categorize as sensitive antibiotics against $S$. aureus and $E$. coli. Based on CLSI (2018), amoxicillin categorizes sensitivity against $S$. aureus if the inhibition zone is $\geq 29 \mathrm{~mm}$, while gentamicin categorizes sensitivity against $\mathrm{E}$. coli if the diameter of the inhibition zone $\geq$ is $15 \mathrm{~mm}$.

The antibacterial activity of methanol jangjingki on the development of $\mathrm{S}$. aureus and $\mathrm{E}$. coli could inhibit the growth of the two bacteria extracts; the highest zone was obtained from a concentration of $40 \%$ with a diameter of $8,07 \mathrm{~mm}$ and $11 \mathrm{~mm}$ of inhibition zone, respectively. This result is different from research done by Handali et al. (2011), which reported that water extract of jangjingki leaf has the highest inhibition zone at $20 \%$ concentration against $S$. aureus and $E$. coli with a diameter of inhibition zone respectively at 21 $\mathrm{mm}$ and 19,33 mm. Handali et al.'s (2011) research result is better than this research, seen as a result of the inhibition zone. The difference in results can be caused by the part used, solvent, and different test methods. Handali et al. (2011) used leaf and water as a solvent with the disk diffusion method. The difference in activity 
compound content obtained from the same plant is presumably caused by the rate of different secondary metabolite compounds in each plant. The environment of different growing places can cause this, harvesting time, age of the plant, part of the plant that used, and the choice of extraction method (Depkes RI, 2000), where secondary metabolites production influenced by temperature, rainfall, humidity, light, soil characteristic, and nutrition needed by the plant (Astuti et al., 2014). Other than that, Candrasari et al. (2012) said that extract concentration, method, and test media used, the speed of extract diffusion in media, and bacteria properties could also influence antibacterial activity.

Antibacterial activity of jangjingki methanol extract against $E$. coli is higher than against $S$. aureus. Comparison in the percentage of jangjingki methanol extract against $S$. aureus and $E$. coli is $27,42 \%$ in positive amoxicillin control and $52,06 \%$ in positive control of gentamicin. Jangjingki methanol extract can give antibacterial activity because of secondary metabolite content inside jangjingki, for example, alkaloids, flavonoids, tannins, saponins, and steroids the development of $S$. aureus and E. coli. Alkaloids as antibacterial works at disturbing peptidoglycan synthesis where peptidoglycan is the main component for cell wall constituent. If peptidoglycan synthesis is disturbing, then the cell wall layer will not form ultimately and cause the death of the cell itself (Juliantina et al., 2008).

Flavonoid takes part as an antibacterial by inhibiting the function of the cell membrane through forming the complex compound with soluble extracellular protein, so the integrity of cell membrane disturbs and breaks, which causes bacteria intracellular component is out from the cell (Ernawati dan Sari, 2015).

Tannins' role as an antibacterial is by shrinking the wall and cell membrane to disturb cell permeability. As a result, cells can not be lived, which causes the development is slowing down and dead (Ajizah, 2004). Other than that, Suryani et al. (2019) said that tannins work by disturbing the cell wall of polypeptide so that the cell wall formed incompletely. It caused the lysis of bacterial cells affected by osmotic pressure or physically so that they died. Saponins works as an antibacterial by decreasing surface tension which caused the stability of bacterial cell membrane disturbed so that the intracellular compound is out and bacterial lysis cells (Kusumawati et al., 2015).

Steroids work as antibacterial mechanisms by breaking bacterial cell plasma membranes, so that affected cytoplasm leaked and went out from cells which occurred to be lysis of bacterial cells(Wiyanto, 2010).

\section{Antifungal activity tests}

The test result of antifungal activity of jangjingki methanol extract shows that $C$. Albicans does not have acted as an antifungal. Based on Table 3, methanol extract of jangjingki can not form an inhibition zone other than the positive control. This that jangjingki methanol extract can show not inhibit the growth of $C$. Albicans. Nystatin used as a positive control resulted in an inhibition zone of $12.5 \mathrm{~mm}$. Nystatin is an antifungal categorized as sensitive in inhibiting the growth of C. Albicans even though with the medium category, which is at 12-16 mm (Picture 4) (Segismundo et al., 2008).

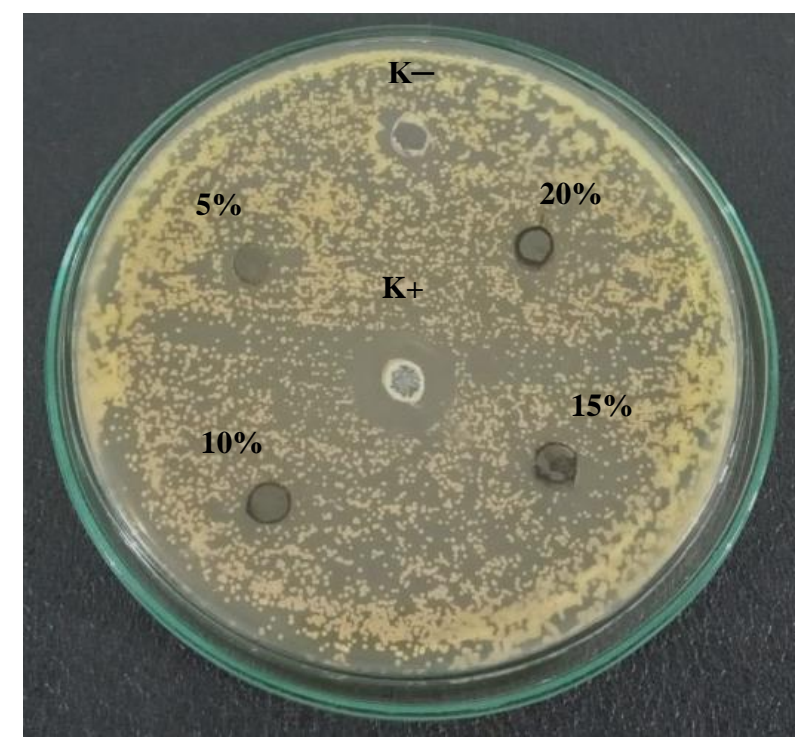

Picture 4. Test results of antifungal activity of jangjingki methanol extract against fungi $C$. Albicans. 
Table 3. The measurement result of antifungal activity test of jangjingki Methanol Extracts against C. Albicans.

\begin{tabular}{|c|c|}
\hline Jangjingki Methanol Extract concentration & The average diameter of inhibition zone (mm) $\mathbf{E}$ SD \\
\cline { 2 - 2 }$(\mathbf{\%})$ & C. albicans ATCC 10231 \\
\hline 5 & $0 \pm 0$ \\
\hline 10 & $0 \pm 0$ \\
\hline 15 & $0 \pm 0$ \\
\hline 20 & $0 \pm 0$ \\
\hline Control positive & $12,5 \pm 0,17$ \\
\hline Control negative & $0 \pm 0$ \\
\hline
\end{tabular}

Note :

Control positive: Nystatin

Control negative: Methanol solvent

Test of antifungal activity jangjingki methanol extract against $C$. Albicans does not result in an inhibition zone. Presumably, this can happen because of the small concentration of extract that cannot inhibit fungus growth. The research done by Tibuhwa (2016) reported that jangjingki leaf water extract resulted in the diameter of the inhibition zone against $C$. Albicans ATCC 90028 was at $4 \mathrm{~mm}$.

Research by Herwin and Nuryanti (2012) reported that the squeeze of jangjingki herbs at $50 \%$ concentration resulted in the diameter of the inhibition zone against $C$. Albicans was at $15,00 \mathrm{~mm}$. The difference in results about the inhibition zone obtained is suspected because of the difference in secondary metabolites inside the plant. The factor of not having antifungal activity against C. Albicans is the complexity of the fungus cell wall structure. The cell wall structure layered with six layers outside to inside: a fibrillar layer, mannoprotein, $\beta$-glucan, $\beta$-glucan-chitin, mannoprotein, and plasma membrane (Mutiawati, 2016). Chitin is one of the essential parts in the fungus cell wall because it works which suspected in keeping the integrity of cell wall structure which is also suspected as a cause on why secondary metabolites compound hardly diffuses inside the fungus cell wall, so that affects in not forming antifungal activity of jangjingki methanol extract (Tyasrini et al., 2006).

Other than that, Candrasari et al. (2012) said that extract concentration, method and test media used, speed of diffusion extract, and fungus property could be some of the influences of obtaining antifungal activity.

Jangjingki methanol extract contains alkaloids, tannins, flavonoids, steroids, and saponins compounds. Alkaloids as antifungal works by breaking cells membrane that results in cells death. Tannins' role as an antifungal is to precipitate the protein by creating insoluble liquid. (Candrasari et al., 2012). Flavonoids role as an antifungal is to denature protein that causes cells membrane permeability to increase so that cells become breaking and dying. Steroids' role as an antifungal inhibits nucleic acid biosynthesis and replaces the fungal cell constituent (Nuryanti et al., 2016). At the same time, saponin's role is to cause a disturbance to the stability of fungal cell membranes, which causes a lysis of fungal cells (Kusumawati et al., 2015). However, in this research, jangjingki methanol extract does not inhibit the growth of $C$. Albicans, even positively contains secondary metabolites compounds like alkaloids, tannins, flavonoids, steroids, and saponins. This is presumed because of the small number of actively secondary metabolites inside the extract so that it cannot inhibit the growth of $C$. Albicans.

Meanwhile, the phytochemistry test that has been done in this research is only qualitative, so we are not sure how much metabolites compound is contained inside the extract. Other than that, this kind of metabolites compound in this plant can reduce the resulting 
activity, where this type of secondary metabolites compound is only a derivative from metabolites compound which has different structures from its active metabolites, so the activation as an antifungal is going to be different even though in the same group. This type of secondary metabolites can be the cause of not having antifungal activity.

\section{CONCLUSION}

Jangjingki has the potential to become antibacterial. Jangjingki methanol extract at $40 \%$ concentration can obtain the highest inhibition zone, $8,07 \mathrm{~mm}$ against $S$. aureus and $11 \mathrm{~mm}$ against $E$. coli but still not enough to inhibit C. Albicans.

\section{REFERENCES}

Ahmed, D., Zara, S., \&Baig, H. (2013). In vitro analysis of antioxidant activities of Oxalis corniculata Linn. fractions in various solvents, 10(1), 158-165.

Ajizah, A. (2004). Sensitivitas Salmonella typhimurium Terhadap Ekstrak Daun Psidium guajava L.. BIOSCIENTIAE, 1(1), 31-38.

Anief, M. (2010). Ilmu Meracik Obat. Penerbit Universitas Gadjah Mada Press, Yogyakarta.

Astuti, E., Sunarminingsih, R., Jenie, U. A., Mubarika, S., \& Sismindari. (2014). Pengaruh Lokasi Tumbuh, Umur Tanaman dan Variasi Jenis Destilasi Terhadap Komposisi Senyawa Minyak AtsiriRimpangCurcuma mangga Produksi Beberapa Sentra di Yogyakarta. J Manusia dan Lingkungan, 21(3), 323-330.

Brooks, G.F., Janet, S.B., \&Stephen, A.M. (2007). Jawetz, Melnick and Adelbergs, Mikrobiologi Kedokteran edisi23. Terjemahan oleh Mudihardi, E., Kuntaman, Wasito, E.B., Mertaniasih, N.M., Harsono, S., dan Alimsardjono, L. Penerbit Buku Kedokteran EGC, Jakarta.
Candrasari, A., Romas, M. A., Hasbi, M.,\&Astuti, O. R. (2012). Uji Daya Antimikroba Ekstrak Etanol Daun Sirih Merah (Piper Crocatum Ruiz \& Pav.) Terhadap Pertumbuhan Staphylococcus AureusATCC 6538, Eschericia ColiATCC 11229 dan Candida AlbicansATCC10231 secara In Vitro. Biomedika, 4(1), 9-16.

Clinical and Laboratory Standards Institute. (2018). Performance Standards for Antimicrobial Susceptibility Testing; Twenty-Fourth Informational Supplement 28th ed. CLSI document M100-S24, USA.

Denovix Inc. (2017). OD600 Measurement. Denovix, Us.

Departemen Kesehatan Republik Indonesia. (2000). Parameter Standar Umum Ekstrak Tumbuhan Obat edisi kesatu. Direktorat Jendral Pengawasan Obat dan Makanan, Jakarta.

Dighe, S. B., Kuchekar, B. S., \& Wankhede, S. B. (2012). Pharmacological Evaluation of Oxalis corniculata Linn for Anthelmintic Activity. Journal of Pharmacology and Pharmacodynamics, 4(1), 1-4.

Dzulkarnain, B., Sundari, D.,\&Chozin, A.(2004). Tanaman Obat Bersifat Antibakteri di Indonesia. Cermin Dunia Kedokteran, $110,35-43$.

Ernawati \& Sari, K. (2015). Kandungan Senyawa Kimia dan Aktivitas Antibakteri Ekstrak Kulit Buah Alpukat (Persea americana P.Mill) Terhadap Bakteri Vibrio alginolyticus. Jurnal Kajian Veteriner, 3(2), 203-211.

Gayo, R. P.(2018). Uji Efek Antelmintik Ekstrak Metanol Jangjingki (Oxalis corniculataL.) Terhadap Cacing Ascaridia gallisecara In Vitro (Tugas Akhir). Universitas Syiah Kuala, Banda Aceh. 
Handali, S., Hosseini, H., Ameri, A., \& Moghimipour, E. (2011). Formulation and evaluation of an antibacterial cream from Oxalis corniculata aqueous extract. Jundishapur Journal of Microbiology, 4(4), 255-260.

Herwin \& Nuryanti, S. (2012). SkriningAktivitas Antimikroba Ekstrak Herba Belimbing Tanah (Oxalis Corniculata L.) secara KLT-Bioautografi dan Difusi Agar. AsSyifaa, 4(1), 74-81.

Husni, E., Suharti, N., \& Atma, A. P. T. (2018). Karakterisasi Simplisia dan Ekstrak Daun Pacar Kuku (Lawsonia inermis Linn) serta Penentuan Kadar Fenolat Total dan Uji Aktivitas Antioksidan. Jurnal Sains Farmasi dan Klinis, 5(1), 12-16.

Juliantina, F. R., Citra, D. A. M., Nirwani, B., Nurmasitoh, T., \& Bowo, E. T. (2008). Manfaat Sirih Merah (Piper crocatum) sebagai Agen Anti Bakterial Terhadap Bakteri Gram Positif dan Gram Negatif. JKKI - Jurnal Kedokteran dan Kesehatan Indonesia, 1(1), 12-20.

Kusumawati, E., Supriningrum, R., \& Rozadi, R. (2015). Uji Aktivitas Antibakteri Ekstrak Etanol Daun Kecombrang Etlingera elatior (Jack) R.M.Sm Terhadap Salmonella typhi. Jurnal Ilmiah Manuntung, 1(1), 1-7.

Lingga, A. R., Pato, U., \& Rossi, E. (2016). UjiAntibakteri Ekstrak Batang Kecombrang (Nicolaia speciosa Horan) Terhadap Staphylococcus aureusdanEscherichia coli. JOM Faperta, 3(1), 1-15.

Litaay, M., Sari, K., Gobel, R. B., \& Haedar, N. (2017). Potensi Abalon Tropis Haliotis asinina L. Sebagai Sumber Inokulum Jamur Simbion Penghasil Antimikroba. SPERMONDE, 3(1), 42-46.

Menteri Kesehatan Republik Indonesia. (2009). FarmakopeHerbal Indonesia edisi pertama. Kementerian Kesehatan RI, Jakarta.

Mohan, S. M., \& Pandey, B. (2016). Antimicrobial Activity of Oxalis corniculata Linn.International Journal of Science and Research, 5(7), 575-578.

Mutiawati, V. K. (2016). Pemeriksaan Mikrobiologi pada Candida albicans.Jurnal Kedokteran Syiah Kuala, 16(1), 53-63.

Ningsih, D. R., Zusfahair., \& Kartika, D. (2016). Identifikasi Senyawa Metabolit Sekunder serta Uji Aktivitas Ekstrak Daun Sirsak Sebagai Antibakteri. Molekul, 11(1), 101-111.

Nur, R. M., Mu'nisa, A., \& Hala, Y. (2019). Skrining Fitokimia Ekstrak Metanol Karang Lunak (Lobophytum sp.). Jurnal Bionature, 20(1), 57-63.

Nuryanti, S., Mustapa, K., \& Sudarmo, I. G. (2016). Uji Daya Hambat Ekstrak Buah Kelor (Moringa oleifera Lamk) Terhadap Pertumbuhan Jamur Candida albicans. Jurnal Akademika Kimia, 5(4), 178-184.

Pratiwi, S. T. (2008). Mikrobiologi Farmasi. Erlangga, Jakarta

Reo, A. R., Berhimpon, S., \& Montolalu, R. (2017). Metabolit Sekunder Gorgonia (Paramuricea clavata). Jurnal IImiah Platax, 5(1), 42-48.

Salman, S. (2018). Use Of Grid Computing Infrastructures For In-Silico Drug Discovery And Drug Design: A Review. Jurnal Stikna, 2(2).

Segismundo, A. B., Florendo, P. E., \&Pablico, A. R. P. (2008). In vitro Antifungal Activity and Phytochemical Screening of Gouania javanica Miq. Leaves. UNP Research Journal, 17, 1-10.

Siddiqui, M. A., Singh, R. K.\& Kumar, A.(2017). Phytochemical screening and antibacterial activity of Oxalis 
corniculata against human pathogens. International Journal of Current Research, 9(12), 62114-62118.

Suryani, N., Nurjanah, D., \& Indriatmoko, D. D. (2019). Aktivitas Antibakteri Ekstrak Batang Kecombrang (Etlingera elatior (Jack) R.M.Sm.) Terhadap Bakteri Plak Gigi Streptococcus mutans. Jurnal Kartika Kimia, 2(1), 23-29.

Tansil, A. Y. M., Nangoy, E., Posangi, J., \& Bara, R. A. (2016). Uji Daya Hambat Ekstrak Etanol Daun Srikaya (Annona squamosa) Terhadap Pertumbuhan Bakteri Escherichia coli dan Staphylococcus aureus. Jurnal eBiomedik (eBm), 4(2).

Tibuhwa, D. D. (2016). Oxalis corniculata L. In Tanzania: traditional use, cytotoxicity, and antimicrobial activities. Journal of Applied Biosciences, 105, 1005510063.

Tyasrini, E., Winata, T., \& Susantina. (2006). Hubungan antara Sifat dan Metabolit Candida spp. dengan Patogenesis Kandidiasis. JKM, 6(1), 52-67.

Wiyanto, D. B. (2010). Uji Aktivitas Antibakteri Ekstrak Rumput Laut Kappaphycus alvareziidanEucheuma denticullatumTerhadap BakteriAeromonas hydrophiladanVibrio harveyii. Jurnal Kelautan, 3(1), 1-17.

World Health Organization. (2003). Manual for the Laboratory Identification and Antimicrobial Susceptibility Testing of Bacterial Pathogens of Public Health Importance in the Developing World. Switzerland.

World Health Organization. (2009). WHO Laboratory Manual for Diagnosis of Fungal Opportunistic Infection in HIVIAIDS Patients, Regional Office for South-East Asia.

Yusriana, C. S., Budi, C. S.,\&Dewi, T. (2014). Uji Daya Hambat Infusa Daun Nangka
(Artocarpus heterophyllus) Terhadap Pertumbuhan Bakteri Staphylococcus aureus. Jurnal Permata Indonesia, $5(2), 1-7$. 